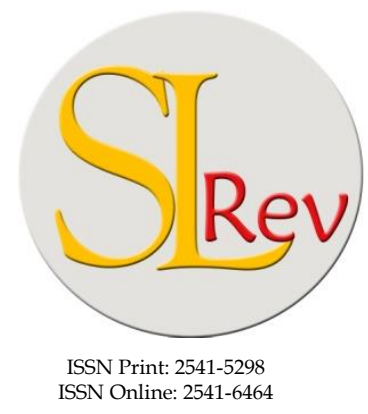

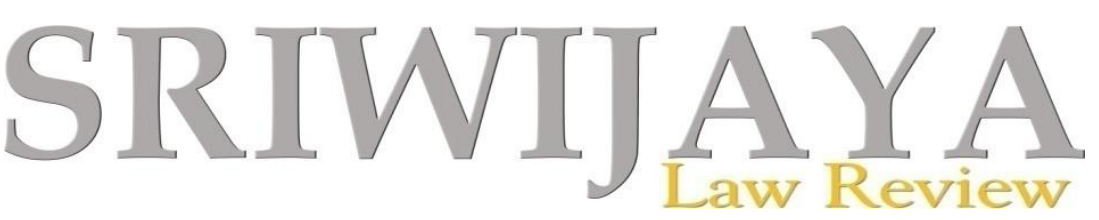

Editorial Office: Faculty of Law, Sriwijaya UniversityJalan Srijaya Negara, Palembang, South Sumatra 30139, Indonesia.

Phone: +62711-580063Fax: +62711-581179

E-mail: sriwijayalawreview@unsri.ac.id| sriwijayalawreview@gmail.com

Website: http://journal.fh.unsri.ac.id/index.php/sriwijayalawreview

\title{
The Effectiveness of the Implementation of Customary Fines in settlement of Seclusion Cases in Banda Aceh
}

\author{
Teuku Muttaqin Mansur, ${ }^{\mathrm{a}}$ Yunita, ${ }^{\mathrm{a}}$ M. Adli, ${ }^{\mathrm{a}}$ and Sulaiman ${ }^{\mathrm{a}}$
}

a Faculty of Law, Universitas Syiah Kuala, Banda Aceh, Indonesia, E-mail: tmuttaqien@unsyiah.ac.id

\begin{tabular}{ll}
\hline Article & Abstract \\
\hline Keywords: & $\begin{array}{l}\text { Seclusion (khalwat) is the activity conducted in a quiet place between two } \\
\text { individuals of different sex who are not mahram (blood relative) without the }\end{array}$ \\
$\begin{array}{l}\text { Customary Fines; Ef- } \\
\text { fectiveness; Settlement } \\
\text { of Khalwat. }\end{array}$ & $\begin{array}{l}\text { legitimate marriage bond and the willingness from both parties, which leads } \\
\text { to adultery. Fine is one of the customary penalties given to the perpetrators } \\
\text { of khalwat. In practice, implemented of fines between one region and anoth- } \\
\text { er is different. The study aims to identify the types of adat fines charged to } \\
\text { khalwat perpetrators and the effectiveness of implementation on the } \\
\text { settlement customary fines in Banda Aceh. It used a juridical-empirical re- }\end{array}$ \\
$\begin{array}{l}\text { Artikel History } \\
\text { Received: Sep 16, 2019; } \\
\text { Reviewed: Jan 12, 2020; } \\
\text { Accepted: Jan 30, 2020; } \\
\text { Published: Jan 31, 2020 } \\
\text { material, also used an in-depth interview with respondents. The data ana- } \\
\text { lyzed using a qualitative descriptive approach. This research conducted in } \\
\text { Banda Aceh district. The research results show that the kind of customary } \\
\text { fines given to khalwat perpetrators was different. There are even some cases } \\
\text { begun to shift, and some considered that being married because of khalwat } \\
\text { was considered one of the customary fines. Customary fines are effective in } \\
\text { 10.28946/slrev.vol4.Iss } \\
\text { 2.404.pp52-61 }\end{array}$ & $\begin{array}{l}\text { reducing offense of khalwat. However, there are concerns if the decision of } \\
\text { the customary fines does not get optimal support from law enforcement offi- } \\
\text { cials. Expected, customary official affirmed kind of customary fine given to } \\
\text { khalwat perpetrators. The difference subtle, need to consider the aspect of } \\
\text { justice, the ability, and effective whereabouts of fines to reduction offense of } \\
\text { khalwat. }\end{array}$
\end{tabular}

(C)2020. This article is an Open Access Research distributed under the term of the Creative Commons Attribution License (https://Creativecommons.org/licences/by/4.0), which permits unrestricted use, distribution, and reproduction in any medium provided the original works is properly cited.

\section{INTRODUCTION}

Customary laws in Indonesia have undergone a long journey of history. After Indonesia declared its liberty on August 17, 1945, the existence of customary laws (read: customary court) has been abolished gradually (Article 1 paragraph (2)). ${ }^{1}$ However, in post-1998's reformation era, the recognition of customary laws was referred to Article 18 B paragraph (2) of the 1945 Constitution. Article 18 B paragraph (2) reads, "The State recognizes and respects traditional communities along

1 “Emergency Law No.1/1951” (n.d.). 
with their traditional customary rights as long as these remain in existence and are following the societal development and the principles of the Unitary State of the Republic of Indonesia and shall be regulated by law." This basic constitution was then made as the reference by Aceh when it recognized customary court through Law No.11/2006 concerning the Governing of Aceh and the interpretation through Qanun of Aceh (Regional Regulation) No.9/2008 concerning the Development of Customary Life and Customs, Qanun of Aceh No.10/2008 concerning Customary Institutions, and the Regulation of Aceh's Governor No.60/2013 concerning the Implementation of Customary Dispute Resolution. One of the important things regulated in Qanun of Aceh No.9 and Governor Regulation of Aceh is the implementation of customary fines in solving khalwat disputes. However, what kind of fines that be imposed and how the effectiveness of the customary fines that be implemented to the khalwat cases, there is no comprehensive study conducted so far regarding these matters.

Khalwat is the activity conducted in closed or hidden places between 2 (two) individuals of different sex who are not mahram (blood relative) without the legitimate marriage bond and the willingness from both parties, which leads to adultery (Article 1 number 23). ${ }^{2}$ Pangiran Mohammad Tashim in Teuku Muttaqin Mansur, ${ }^{3}$ khalwat is a matter which leads to denigration and sin; even more, this matter is also one of the things that bring individuals closer to adultery. Thus, any conduct which leads to adultery can be categorized as khalwat. Usually, those kinds of conduct are done secretively. In its implementation, the perpetrators of khalwat will be imposed by customary fines after underwent a trial process in the village (gampong) customary court.

Some related studies conducted by Abdurrahman ${ }^{4}$ has discussed the dispute resolution through customary approach by focusing on the customary dispute resolution based on the philosophical aspect, legal basis, principles in dispute resolution. Mahdi ${ }^{5}$ studied the existence of the customary court in Aceh, the focus of his study was observing the existence of customary court in the national justice system and the position of customary court on its practice in Aceh. Teuku Muttaqin Mansur ${ }^{6}$ studied the adultery case through gampong customary court in Aceh. However, the discussion was focused on the cause of the verdict taken by the gampong customary court, not related to the effectiveness of the implementation of customary fines toward the perpetrators of khalwat as studied in this study.

Next, Yusi Amdani ${ }^{7}$ studied the process of dispute resolution in the customary justice institution of Aceh at gampong level. However, it was more emphasizing on the discussion toward legal basis, principles, and objectives of the customary justice court, the structure, and scope of responsibility of custom leaders and the implementation of the verdict of the customary court, specific matters such as customary fines for the perpetrators of khalwat have yet to be studied.

\footnotetext{
“Aceh’s Qanun No.6/2014” (n.d.).

Teuku Muttaqin Mansur et al., "Kewenangan Penyelesaian Kasus Khalwat Melalui Peradilan Adat Di Aceh," Jurnal Hukum Respublica 13, no. 1 (2013): 48-61.

4 Abdurrahman, "Penyelesaian Sengketa Melalui Pendekatan Adat," Kanun Jurnal Ilmu Hukum 12, no. 1 (2010): 127-36.

5 Mahdi, “Eksistensi Peradilan Adat Di Aceh,” Hunafa: Jurnal Studia Islamika 8, no. 2 (2011): 189-215.

6 Teuku Muttaqin Mansur, "Penyelesaian Kasus Mesum Melalui Peradilan Adat Gampong Di Aceh (Suatu Kajian Kasus Di Banda Aceh)," Media Syari'ah 14, no. 1 (2012): 231-43.

7 Yusi Amdani, "Proses Pelaksanaan Penyelesaian Perselisihan Di Lembaga Peradilan Adat Aceh Tingkat Gampong (Desa)," Asy-Syir'ah; Jurnal Ilmu Syari'ah Dan Hukum 48, no. 1 (2014): 231-60.
} 
Taqwaddin Husein, ${ }^{8}$ in his study has indeed started to focus on observing the mechanism of dispute resolution, the existence of customary justice court, and customary institution. However, it has not explained the effectiveness of customary fines in its implementation as what this study does.

Wilsa and M. Nurdin ${ }^{9}$ wrote about the customary resolution dispute, but in general, the study discussed the settlement of misdemeanors, which solved through customary justice court. However, their study has yet to observe the effectiveness of customary fines that be implemented.

Presently, a study that focuses on the effectiveness of customary fines in settlement of khalwat cases in Aceh. Therefore, this research is different from the previous ones. This research focuses on the effectiveness of the implementation of customary fines toward the perpetrators of khalwat in Banda Aceh.

Further, the verdict of customary justice court in deciding the khalwat case between one case to another and between one region to another was tending to be decided differently either from the forms or the types of fines.

This research aims at identifying the type of customary fines imposed on the perpetrators of khalwat and the effectiveness of the implementation of customary fines in resolving khalwat cases in Banda Aceh.

\section{RESEARCH METHODS}

The data obtained through interviews toward five respondents in Banda Aceh, as well as a literature review of primary and secondary legal materials. It is head and secretary of village Lamgugob, Peulanggahan, and Ateuk Jawo, Rukoh. The acquired data were analyzed by using a qualitative descriptive approach. The determination of sample in research used purposive sampling technique toward the selected respondents, while the in-depth interview was used as the data collecting technique in this research by referring to the list of unstructured questions.

\section{ANALYSIS AND DISCUSSION}

Besides the term customary court, "customary trial" or "customary meeting" is also famous in the settlement process of customary cases. ${ }^{10}$ However, the customary court has become an adhere in the daily life of the community in settling customary disputes.

According to Akhyar Mustafa, ${ }^{11}$ the customary court is the reconciliation locus to solve customary issues. Customary justice is a reconciliation justice system to solve customary issues that occur within the society, including the settlement of khalwat cases.

The customary court is also defined as a process or means to maintain customary material law in the customary court. The parties who violate the provision of customary law (customary

8 Taqwaddin Husin, "Penyelesaian Sengketa/Perselisihan Secara Adat Gampong Di Aceh," Kanun Jurnal Ilmu Hukum 17, no. 3 (2015): 511-32.

9 Et.al Wilsa, "Efektivitas Fungsi Lembaga Adat Aceh Dalam Penyelesaian Tindak Pidana Ringan Di Tingkat Gampong," Jurnal Ilmiah Dunia Ilmu 2, no. 3 (2016): 147-65.

10 Mahdi, "Eksistensi Peradilan Adat Di Aceh," Hunafa: Jurnal Studia Islamika 8, no. 2 (2011): 191.

11 Akhyar Mustafa, "Dasar Hukum Peradialan Adat Di Aceh," 2015, https://www.academia.edu/15603972/Dasar_Hukum_Peradilan_Adat_di_Aceh, retrieved on June 152018. 
material law) can be brought before the board of customary judges to be put in trial. Reconciliation is usually achieved by the end of the customary settlement process. ${ }^{12}$

Despite many questions aimed toward the normative framework, however, in reality, the practices of criminal case settlement outside the primary judiciary system performed by customary justice institutions exist. ${ }^{13}$

In association with this article, the customary court in a discussion is the judiciary, which contributed to the settlement of khalwat violation cases that occur in Banda Aceh.

\section{The Settlement of Customary Disputes}

The implementation of customary fines is performed after the customary court concludes its verdict. The implementation of customary court itself has owned strong legal basis because it is based on Article $18 \mathrm{~B}$ paragraph (2) which recognizes the existence of customary law society and their traditional rights, Law No.11/2006 concerning the Governing of Aceh (UUPA), and Qanun of Aceh No.9/2008 concerning the Development of Customary life and Customs, and the Governor Regulation of Aceh No.60/2013 concerning the Settlement of Customary Disputes.

Article 13 paragraph (1) of Qanun of Aceh No.9/2008 mentions that 18 types of dispute can be solved through customary court such as the dispute within households, dispute between families which associated with faraidh, the dispute between citizens, khalwat, the dispute regarding the right of ownership, the thievery in family, the dispute regarding the seuhareukat property (shared property), petty theft, cattle raiding, the customary offense regarding cattle, agriculture, and forest, the dispute at sea, the dispute in markets, mild persecutions, the forest burning, harassments, defamations, incitements, libels, environmental pollution (mild scale), intimidations, and other disputes that violate customs. If there is a violation against those 18 (eighteen) cases, including khalwat, thus, the settlement will be done through the mechanism of customary court.

Formally, the settlement mechanism through the customary court as stipulated by Article 17 of Aceh's Governor Regulation No.60/2013 concerning the Settlement of Customary Disputes as illustrated in Figure 1.

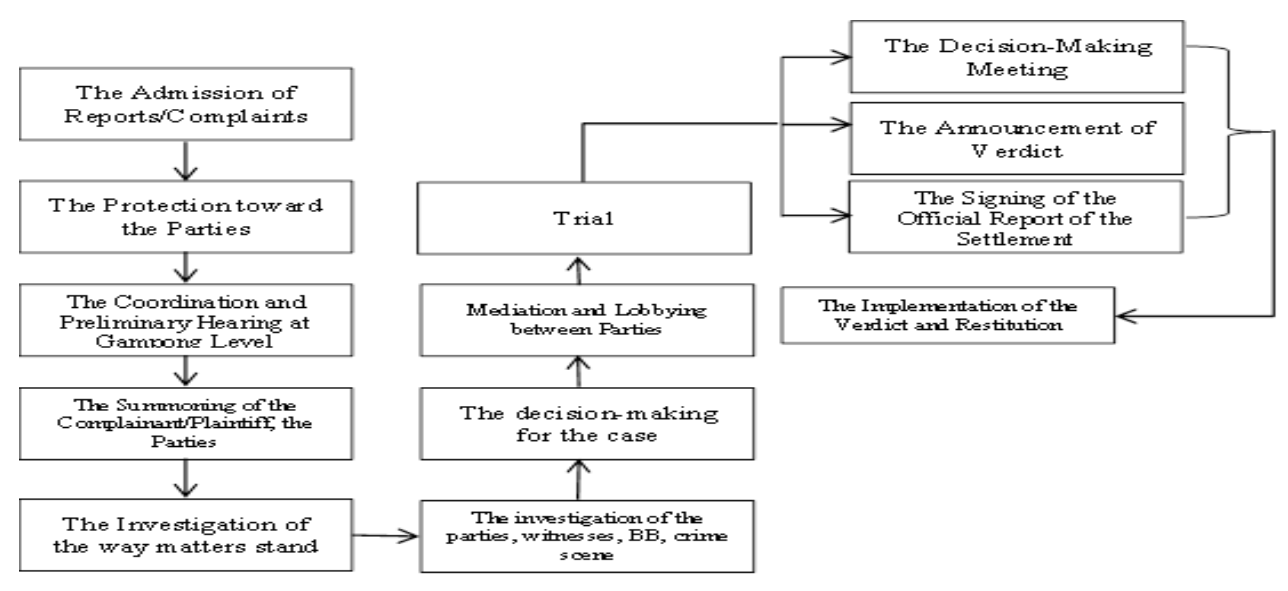

Figure 1. Settlement Mechanism of Customary Disputes based on Governor Regulation

\footnotetext{
12 Teuku Muttaqin Mansur, Hukum Adat Perkembangan Dan Pembaruannya Di Indonesia (Banda Aceh: Bandar Publishing, 2017).

13 Mansur.
} 
Figure 1 explains that the dispute resolution is started with the action from customary officials, namely: keuchik/village head, tuha peut/Village Advisory Council receives a report/complaint from the community regarding the customary violation conducted by a person. If the complaint contains truth, thus, the customs official will protect the parties in dispute. This action is meant to prevent the act of 'vigilantism' or 'frontier justice' conducted by citizens who catch the offenders.

The next stage is the coordination between customary officials and the related parties, the preliminary hearing, the summoning of the plaintiff, and the parties in disputes. After that, keuchik and tuha peut investigate the way matters stand, questioning the mistake conducted by the offenders, and the actual chronology. The chronology of events does not only ask toward the offenders but also to the plaintiff and the witness who saw the event.

Based on that information, the next stage, according to Article 17 of Aceh's Governor Regulation, is deciding whether the case will be brought to customary court to be put on trial or will be solved outside the customary justice/court.

If the case that is reported does not provide sufficient evidence, thus, the offenders will be released or be returned to their families. However, in the situation of the case which contains truth, thus, the status of the case will be delegated and solved through gampong customary court.

In the settlement process, keuchik (village head) acts as a customary presiding judge, tuha peut acts an advisory council of customary court, imeum meunasah (imam of a mosque) is positioned as the consultant while village secretary will act as a court clerk.

If all parties in the customary court are present; thus, the trial will be continued with the agenda of the verdict. The verdict is taken through the way of deliberation. After the verdict has been reached, then, Keuchik as the presiding judge of the customary court will announce the verdict toward all parties who present in the customary court.

The final mechanism of the settlement process of disputes in customary court is the signing of the official report of dispute resolution, which has been prepared by the Clerk (Village Secretary) and then the implementation of the verdict.

In the khalwat cases, the implementation of the verdict is accompanied by fines toward the offenders. However, the fines that be imposed between one village to another is different.

\section{The Types of Customary Fines}

The imposition of customary fines toward the offenders of customs is stipulated firmly in Article 16 paragraph (1) of Qanun of Aceh No.9/2008, and Article 20 of the Aceh's Governor Regulation No.60/2013 concerning the Implementation of the Settlement of Customary Disputes di Aceh. The customary sanctions which can be applied in accordance with the regulations are a) advice, b) warning, c) statement of apology, d) sayam (form of compensation in the form of property given ${ }^{14}$, e) diyat (soul or limb lost or damaged by the property) ${ }^{15}, \mathrm{f}$ ) fines, g) compensation, h) exclusion, i) driven out of gampong, j) the revocation of customary title and other forms of sanction based on the local customs. Specifically, for the case of khalwat, the research result

\footnotetext{
14 Agus Supriono, "Indigenous Ritual as Adhesive Social Harmonization: The Meaning of 'Peusijuek' for Young People of Aceh, Indonesia," Advances in Social Science, Education and Humanities Research (ASSEHR), Antlantis Press 108 (2018): 146-59.

15 Supriono.
} 
in Banda Aceh showed that, in general, customary fines as the common sanction that is imposed. However, the imposition of that sanction is still varied.

For instance, according to the research result in Peulanggahan Village of Banda Aceh City, the perpetrators of khalwat will be imposed by a fine of one goat, whether it is a man or woman. In addition, in Peulanggahan Village, the perpetrators are usually will be put in marriage. In some instances, the settlement of khalwat cases is accompanied by peusijuek ritual (plain flour) and a perfunctory feast. This activity is aimed at the statement toward citizens that the khalwat case managed by the customary court has been settled. ${ }^{16}$

In Lamgugob Village, ${ }^{17}$ Ateuk Jawo Village, ${ }^{18}$ and Peulanggahan Village ${ }^{19}$ of Banda Aceh City, the perpetrators of khalwat will be imposed by a fine of 1 (one) goat. In addition, in addition, in Peulanggahan Village, the perpetrators are usually will be put in marriage.

In some instances, the settlement of khalwat cases is accompanied by peusijuek ritual (plain flour) and a perfunctory feast. This activity is aimed at the statement toward citizens that the khalwat case managed by the customary court has been settled. ${ }^{20}$

However, in Ateuk Jawo Village, the fine of the slaughtering of 1 goat is converted to the obligation to pay a specific amount of money to the gampong. The unique thing is, the research result in Rukoh Village of Banda City indicated that the perpetrators of khalwat would not be imposed by a fine of the slaughtering of the goat. Rukoh Village implements a customary sanction by evicting the perpetrators out of the village. ${ }^{21}$

The village head of Rukoh, Hamidi argued, ${ }^{22}$ the settlement of khalwat cases which solved in Rukoh Village should not contradict Islamic Sharia applied in Aceh. "Masak urueng khalwat juet tabloe ngon peng, nyan kon melanggar syari'at" (people who conduct khalwat should not be fined by some amount of money as the sanction, this action violates Islamic Sharia).

For the people of Rukoh, the fine of goat imposed on the perpetrators of khalwat is considered as violating the Islamic teachings that being obeyed and practiced by the people of Aceh. What supposed to be done when there is an individual who conducts khalwat is through formal way by handling them to Wilayatul Hisbah Police (Sharia Police) as the authorized party.

The authority of Wilayatul Hisbah (WH) Police in managing the case of violation of Sharia, including khalwat is based on Qanun of Aceh No.7/2013 concerning the Procedural Law of Jinayat. Article 1 number 14 of Qanun of Aceh No.7/2014 mentions that Wilayatul Hisbah Police starting now referred to as WH Police is the member of WH that is functioned to conduct the socialization, supervision, enforcement, and guiding of the implementation of Islamic Sharia.

Therefore, the settlement mechanism of khalwat cases, which is implemented in Rukoh Village, is different from other villages and also different from the provision in Article 17 of Aceh's Governor Regulation No.40/2013 as elucidated above.

The detail of the settlement mechanism of khalwat cases in Rukoh Village of Banda Aceh is illustrated in Figure 2:

16 Ferdiansyah, "The Secretary of Gampong Peulanggahan, Interview, May 26, 2018," n.d.

17 Zul, "The Head of Tunggai Hamlet of Gampong Lamgugob, Interview, May 10, 2018," n.d.

18 Munawar, "The Secretary of Gampong Ateuk Jawo, Interview, May 24, 2018," n.d.

19 Ferdiansyah, "The Secretary of Gampong Peulanggahan, Interview, May 26, 2018."

20 Zul, "The Head of Tunggai Hamlet of Gampong Lamgugob, Interview, May 10, 2018."

21 Hamidi, "Head of Gampong Rukoh, Interview, May 23, 2018," n.d.

22 Hamidi. 


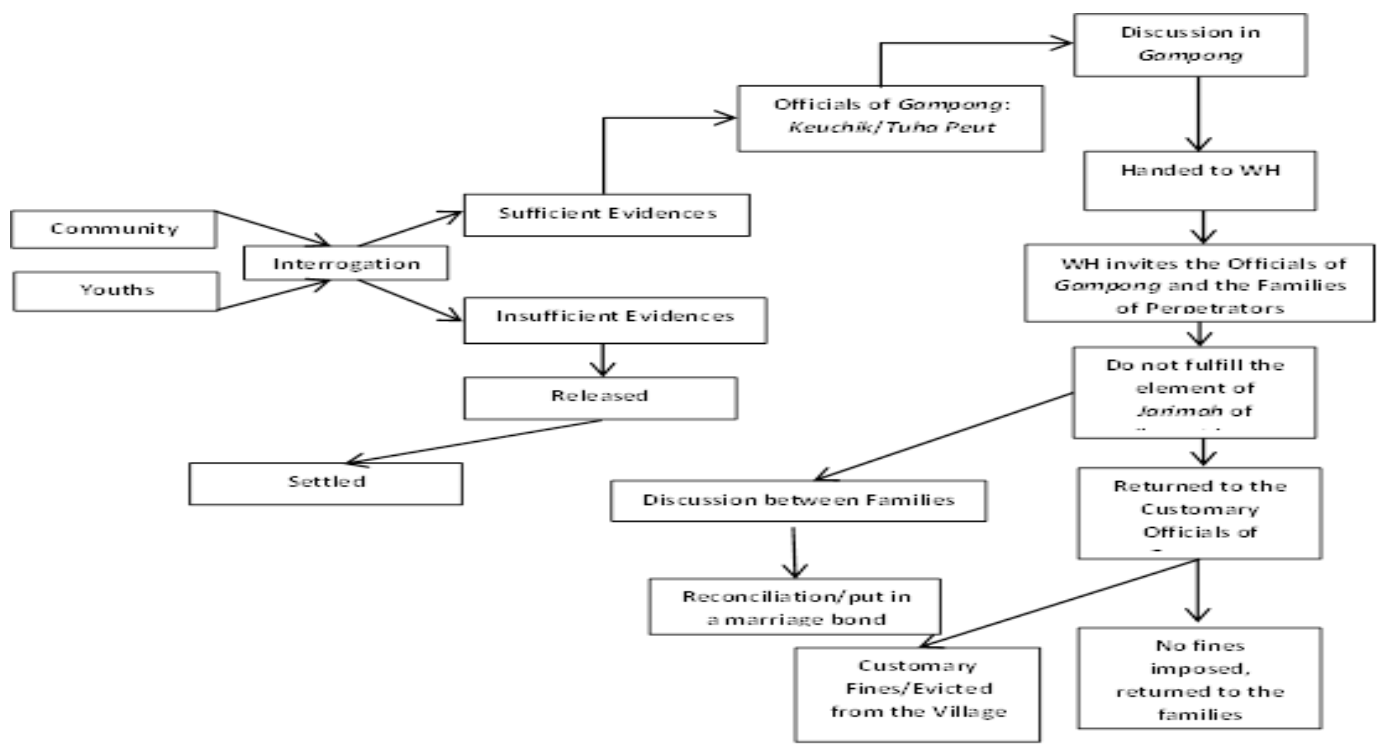

\section{Figure 2. The Settlement Mechanism of Customary Disputes in Gampong Rukoh}

Figure 2 explains that if the perpetrators that are caught and interrogated is not proved as conducting khalwat; thus, they will be immediately released by the community/youths. In this context, the community and youths of the gampong act as the supervisor of Sharia in the gampong. However, if sufficient evidence is found, including the confession from the perpetrators, thus, the perpetrator will be handed to the customary official (keuchik) to be settled through gampong customary court.

In Gampong Rukoh, khalwat cases are also one of the authorities of Sharia Court, aside from the responsibilities of customary court in which their initial management is conducted by the staff of WH. Other cases will be solved through the customary court of Gampong Rukoh. If the investigation results conducted by WH show insufficient evidence, thus, the related families will be summoned, or the settlement will be returned to the officials of gampong. In cases of which the settlement will be done by the officials of gampong, so the verdict will be discussed with the perpetrators' families. In several cases, the perpetrators families agreed to put both perpetrators in a marriage bond. However, at the same time, the officials of gampong will also impose a sanction by evicting or not allowing the perpetrators to live back in Rukoh Village. ${ }^{23}$

The prohibition to no longer live in the gampong is based on the consideration in which the perpetrators are perceived as desecrated the gampong and potentially will do the same thing or affect other people in conducting the same thing in the future. ${ }^{24}$

Another fact shows that the implementation of customary fines in the last couple of years has not been as strict as before, even sometimes the perpetrators of khalwat were not imposed by any fines. In addition, in several cases, the perpetrators of khalwat are actually facilitated to get married after the agreement between families of both perpetrators have been achieved. ${ }^{25}$

Although consider the marriage of the perpetrators as a fine, but the research result indicated that the marriages occurred between perpetrators were due to the agreement between families,

23 Hamidi.

24 Munawar, "The Secretary of Gampong Ateuk Jawo, Interview, May 24, 2018."

25 Zul, "The Head of Tunggai Hamlet of Gampong Lamgugob, Interview, May 10, 2018." 
not based on the customary decision. The marriage as the cause of conducting khalwat has become the issue that grows amidst the citizens of Aceh, whether it is categorized as customary fines or not.

In its development, it has been found that there is a shift in the way of thinking of the modern people who live with the guidance from law regulations. It condition which causes the shifting of some implementations of fines or customary sanctions.

\section{Effectiveness of Customary Fines}

The implementation of customary fines for the perpetrators of khalwat in Banda Aceh has been considered as successful in decreasing the number of khalwat offenses. This condition is reflected from the argument of Ferdiansyah ${ }^{26}$ who stated the settlement through the mechanism of the customary court is highly effective. In the past year, the perpetrators of khalwat have been rarely found in Peulanggahan Village. According to him, customary fines have been capable in reducing the recurring of the similar case as well. Same thing has occurred in Gampong Ateuk Jawo. According to Munawar, the Secretary of Gampong Ateuk Jawo, the imposition of customary fines toward the perpetrators of khalwat has been considered as useful.

In 2012, there were some cases of khalwat which occurred in Gampong Ateuk Jawo, and the perpetrators then got imposed by fines. ${ }^{27}$ The impact of fines' imposition toward the perpetrators of khalwat can be proved by the minimum khalwat cases found in the village. ${ }^{28}$ The decreasing number of khalwat cases can also be proved by the minimum amount of khalwat cases managed by the Sharia Court of Banda Aceh. In 2016, there were 7 cases that reported to the Sharia Court while there is no single case decided by the Sharia Court in $2017 .{ }^{29}$

The data above shows that the settlement of khalwat cases at a custom level has been in line with the number of khalwat cases that have to be managed by Sharia Court. Thus, the more effective the settlement of khalwat at the level of the customary court will reduce the cases reported in WH and Sharia Court of Banda Aceh.

The imposition of customary fines is considered as valid because the settlement performed through customary court does not side with a particular party, and once the issue has been solved through customary laws, the implementers of the customary laws will not bring the incident again and the name of the perpetrators will remain good in the perspective of the society. Different from the State Law in which when a dispute is solved by the police. The offenders who proved as guilty and punished with imprisonment will have difficulty in restoring their reputation as it used to be once they go out of jail. In a meaning that, the offenders will still be labeled as an ex-convict, even though they have been free from their sentences.

Another thing that encourages the implementation of customary fines to be applied effectively is because the imposition of customary fines toward the perpetrators of khalwat is based on reconciliation and agreement, not based on coercion. The reconciliation is achieved after the agreement between both offenders/perpetrators, and the families of them have been reached.

\footnotetext{
Ferdiansyah, "The Secretary of Gampong Peulanggahan, Interview, May 26, 2018."

Munawar, "The Secretary of Gampong Ateuk Jawo, Interview, May 24, 2018."

Munawar.

29 Iqlima, “The Young Clerk of Sharia Court of Aceh, Interview, May 31, 2018," n.d.
} 
Therefore, according to the study of effectiveness, the research showed that customary fines work effectively in preventing the same violation from occurring, either by the same perpetrators or by other individuals.

\section{CONCLUSION}

Although the imposition of customary fines varies between one case to another, between one region to another, customary fines are evidently able to reduce the number of khalwat violations in Banda Aceh. The comprehension regarding the imposition of customary fines starts to shift, and the discrepancy among the society has started to emerge in which facilitating the marriage for the perpetrators of khalwat is considered by the part of the society as customary sanctions or fines. Although in the journey of history, the implementation of customary fines on the perpetrators of khalwat has yet to own authentic or valid reference in which being put in a marriage bond due to conducting khalwat is one of the customary fines.

It is expected that the customs officials will reassert the type of customary fines that will be imposed on the perpetrators of khalwat. The differences in customary fines need to consider the aspects of justice, capability, and the effectiveness of the fines in decreasing the violation of khalwat.

\section{REFERENCES}

Abdurrahman. "Penyelesaian Sengketa Melalui Pendekatan Adat." Kanun Jurnal Ilmu Hukum 12, no. 1 (2010): 127-36.

Aceh's Qanun No.6/2014 (n.d.).

Amdani, Yusi. "Proses Pelaksanaan Penyelesaian Perselisihan Di Lembaga Peradilan Adat Aceh Tingkat Gampong (Desa).” Asy-Syir'ah; Jurnal Ilmu Syari'ah Dan Hukum 48, no. 1 (2014): $231-60$.

Emergency Law No.1/1951 (n.d.).

Ferdiansyah. "The Secretary of Gampong Peulanggahan, Interview, May 26, 2018,” n.d.

Hamidi. “Head of Gampong Rukoh, Interview, May 23, 2018,” n.d.

Husin, Taqwaddin. "Penyelesaian Sengketa/Perselisihan Secara Adat Gampong Di Aceh." Kanun Jurnal Ilmu Hukum 17, no. 3 (2015): 511-32.

Iqlima. “The Young Clerk of Sharia Court of Aceh, Interview, May 31, 2018,” n.d.

Mahdi. "Eksistensi Peradilan Adat Di Aceh.” Hunafa: Jurnal Studia Islamika 8, no. 2 (2011): 191.

. "Eksistensi Peradilan Adat Di Aceh.” Hunafa: Jurnal Studia Islamika 8, no. 2 (2011): 189-215.

Mansur, Teuku Muttaqin. Hukum Adat Perkembangan Dan Pembaruannya Di Indonesia. Banda Aceh: Bandar Publishing, 2017.

_. "Penyelesaian Kasus Mesum Melalui Peradilan Adat Gampong Di Aceh (Suatu Kajian Kasus Di Banda Aceh).” Media Syari'ah 14, no. 1 (2012): 231-43.

Mansur, Teuku Muttaqin, Hamdani Zainal Abidin, Faridah Jalil, and Jasri Jamal. "Kewenangan Penyelesaian Kasus Khalwat Melalui Peradilan Adat Di Aceh.” Jurnal Hukum Respublica 13, no. 1 (2013): 48-61. 
Munawar. "The Secretary of Gampong Ateuk Jawo, Interview, May 24, 2018,” n.d.

Mustafa, Akhyar. "Dasar Hukum Peradialan Adat Di Aceh," 2015. https://www.academia.edu/15603972/Dasar_Hukum_Peradilan_Adat_di_Aceh, retrieved on June 152018.

Supriono, Agus. "Indigenous Ritual as Adhesive Social Harmonization: The Meaning of 'Peusijuek' for Young People of Aceh, Indonesia." Advances in Social Science, Education and Humanities Research (ASSEHR), Antlantis Press 108 (2018): 146-59.

Wilsa, Et.al. "Efektivitas Fungsi Lembaga Adat Aceh Dalam Penyelesaian Tindak Pidana Ringan Di Tingkat Gampong.” Jurnal Ilmiah Dunia Ilmu 2, no. 3 (2016): 147-65.

Zul. "The Head of Tunggai Hamlet of Gampong Lamgugob, Interview, May 10, 2018,” n.d. 